\title{
Parental Involvement in Students' English Writing Competence: A Model at Chinese Junior Middle School
}

\author{
Hongqiong $\operatorname{Sun}^{1} \&$ Sorabud Rungrojsuwan ${ }^{2}$ \\ ${ }^{1}$ School of Foreign Languages and Literature, Chuxiong Normal University, Yunnan, China \\ ${ }^{2}$ School of Liberal Arts, Mae Fah Luang University, Chiang Rai, Thailand \\ Correspondence: Hongqiong Sun, School of Foreign Languages and Literature, Chuxiong Normal University, \\ Chuxiong, Yunnan, China. E-mail: 1183613440@qq.com
}

Received: January 3, 2019

Accepted: January 23, 2019

Online Published: January 31, 2019

doi:10.5539/ach.v11n1p41

URL: https://doi.org/10.5539/ach.v11n1p41

\begin{abstract}
This paper provides an in-depth research into parental involvement at Chinese urban Junior Middle School. Parental involvement plays a substantial role in developing student's English writing competence as long as parents are fully aware of skills of parental involvement. The present study constructs the model of parental involvement in terms of helping students' English writing at Junior Middle School by qualitative interviews and documentation based on Brown's parental formula in Chinese English learning context. Physical capital, together social capital and human capital will predict students' English writing competence. The model demonstrates what may be included in Chinese parents' physical capital, social capital and human capital in detail. However, the model is constructed from the perspectives of English writing in Chinese culture, hence it might be a good hint for parental involvement in Asian context.
\end{abstract}

Keywords: Chinese Junior Middle School, Model, Parental Involvement, Students' English Writing Competence

\section{Introduction}

Parental involvement is defined as parent's full participation with all the available resources in children's English learning process within the English learning setting and the experiences with their children. Numerous studies have confirmed that parental involvement has a unique and essential effect on children's learning. Especially in urban area, parental involvement plays a significant role in students' academic achievement (Desforges \& Abouchaar, 2003; Jeynes, 2005; Cheung \& Pomerantz, 2011). When parents are involved in school, attendance is higher, students show more attention in the classroom, their test scores are higher, behavior improves, and learning difficulties are identified sooner (Daubert \& Epstein, 1993). Furthermore, parental involvement is conspicuous in determining how well students accomplish in school at both the elementary and secondary school levels (Kashahu et al., 2014; Mau, 1997; Muller, 1998; Singh et al., 1995).

However, most of the research of parental involvement in secondary school here are mainly studied in America and other countries instead of China. Furthermore, many researchers have surveyed the studies of parental involvement on some certain subjects. For examples, the impact of parental involvement emerges in mathematics achievement (Peressini, 1998; Shaver \& Walls, 1998); reading achievement (Jeynes, 2003, 2005, 2007; Shaver \& Walls, 1998), and in other subjects as well (Jeynes, 1998, 2003, 2005, 2006, 2007; Zdzinski, 1996). They do not survey English as the second language learning in their research subject. Consequently, most individual studies can provide little guidance to parents and educators on the model of parental involvement in specific subjects (Christian et al., 1998). In addition, most of the studies are cross-sectional instead of longitudinal ones (McBride \& Lin, 1996; Muller, 1998; Peressini, 1998).

In China, the role of family in children's development has been overwhelmed in Confucian philosophies. Academic achievement has been significant social connotation for children and parents in China. However, unlike American parental involvement research, research of parental involvement in China is not systematic and lack of normative analysis (Wang, 2015). English in China remains a highly regarded subject since it can be substantial for acceptance to high school and university (Cortazzi \& Jin, 1996; Hu, 2002; Jiang, 2003). It is widely accepted that English academic achievement is a priority for students to become successful in their future 
careers in China (Hu, 2002).

Currently, both New English Curriculum for Chinese Primary Schools and Junior/Senior Middle Schools (2017 Version) and the new syllabus for Junior Middle School (2016 version) provide the specific English writing requirements for students to achieve. However, most of the English teachers at Junior Middle School don't care students' English writing competence. They mainly focus on language use (English words and grammar), and it is rarely to find English writing in their teaching plan (Sun et al., 2017). As a result, a large proportion of students have no clue in English writing structure. Consequently, students in Junior Middle School find one of the biggest obstacles in their English learning is English writing (Jiang, 2003). And it certainly hinders students to take further English learning in terms of English writing (Hu, 2002; Jiang, 2003).

Bourdieu's cultural capital demonstrates parents could be involved in students' learning in terms of parents' economic support, parents' previous learning knowledge, parents' inspiration for students' learning, and some reliable resources parents could provide in helping students' learning. However, Brown's formula is formed based on Bourdieu's social capital in more specific way in connection to parental involvement. Students' learning could infer from parent's physical capital, human capital, and social capital. In short, the model constructed in the study is provided on account of Brown's formula: Learning = Physical capital + Human capital + Social capital.

What is worth mentioning is that $80 \%$ parents have bachelor's degrees due to Chinese increase enrollment in high education, thus making them more competent in helping student' English learning at home. But parents don't know how and when they can help their child learn to write in English to get better academic achievement (Hu, 2002; Sun et al., 2017) even if they are eager to involve.

Notably, even the studies with parental involvement in China is very limited. Some researchers in China have studied reasons why the students' academic achievement declines when they come to higher school (Jiang, 2003; Chao, 1994). They analyzed many factors to list the reasons from the point views of teachers, students and schools (Gao, 2006; Chen et al., 2010). Yingqi Wang (2015) points out that the students' English academic achievement in secondary school could be related to parental involvement. However, she just analyzed the reasons of parental involvement, but failed to construct the model of parental involvement in helping junior middle school students' English learning.

In general, students' English learning as a whole may be surveyed from the aspects of students, teachers (school) and parents based on students' microsystem context (Bronfenbrenner, 1979). In China, there are too many pieces of research on the aspects from both students and teachers/school, but little work on parents to improve students' English learning at any learning level, not to mention students' English writing competence. In addition, parental involvement is considering into Education Act in China. More and more Chinese educators call on parental involvement in children' learning. Consequently, there's a firm need to construct a model of parental involvement based on Brown's formula and students' English learning practice in Chinese culture.

\section{Bourdieu's Cultural Capital and Brown's Parental Involvement Formula}

Bourdieu's cultural capital (1986) remains clear that the cultural and social capital could determine the degree of parental involvement, and it can affect students' learning outcomes. However, practice of parental involvement is one of cultural capital. According to Bourdieu (1986), cultural capital is the aggregation of knowledge, behaviors and skills that one can excavate to illustrate person's cultural competence, and thus his/her social status in society. To sum up, Bourdieu's cultural capital demonstrates parents could be involved in students' learning in terms of parents' economic support, parents' previous learning knowledge, parents' inspiration for students' learning, and some reliable resources parents could provide in helping students' learning. In general, cultural capital could contain physical capital, human capital, and social capital in parental involvement.

According to Coleman (1990), social capital is the most influential family resource for children's academic success. Parents' human capital and physical capital become reliable only if parents use social capital properly. Coleman (1994) confirms that the construction of a student's human capital is a multiplicative role in available ample physical capital and social capital.

Brown (1998) made the further research on parental involvement based on Bourdieu and Coleman. According to Brown (1998), learning indicates students' learning, physical capital refers to learning resources (learning aids, material available for the child), human capital means instructional skills in helping student's learning. Finally, social capital refers to social support, norms and obligations. Brown states that if the three capitals could work together, students benefit the most:

Learning $=$ Physical Capital + Human Capital + Social Capital 
Brown's formula is primarily adopted in the current study to develop student's English writing competence. Given Chinese student's English learning context, parents' physical capital, human capital and social capital would be devised on English writing characteristics and Chinese culture to lead to students' English writing competence accordingly.

\section{Physical Capital in the Model}

Physical capital could be all the resources parents could find and adopt in parental involvement, including learning aids and the available resources parents hold around them. Hence physical capital contains parent's background information, parental available resources, and current situation of students' writing. Parents' background information could be the guarantee term to assure parental involvement practice. The interview for parents and 2 English teachers would be included in the current situation of students' English writing. by understanding the current situations of students' English writing, the model could be more practical and targeted.

The interview for parents was conducted among 15 parents in Chuxiong No. 1 Middle School which it is an urban school. There are 15 parents as the sample size taking part in the interview (see Table 1). All the parents are at work. 12 parents $(80 \%)$ are female, only 3 parents $(20 \%)$ are male. The average age of 15 parents is 42.93 years old. 4 parents $(26.67 \%)$ have their master's degree, while 11 parents $(73.33 \%)$ got their bachelor's degree. The interview for parents is a semi-structured interview to get the information on whether parents know students' English writing and the attitudes to parental involvement in students' English writing competence (see Appendix A).

Table 1. Background information of parents

\begin{tabular}{|c|c|c|c|c|c|}
\hline $\begin{array}{l}\text { Code } \\
\text { parents }\end{array}$ & Age & Gender & $\begin{array}{l}\text { Academic } \\
\text { Degree }\end{array}$ & $\begin{array}{l}\text { How many children do you } \\
\text { have? }\end{array}$ & $\begin{array}{l}\text { Who is mainly responsible for your child's } \\
\text { English learning? }\end{array}$ \\
\hline Parent 1 & 40 & female & Bachelor & 1 & mother \\
\hline Parent 2 & 45 & female & Master & 1 & mother \\
\hline Parent 3 & 45 & male & Bachelor & 1 & mother \\
\hline Parent 4 & 41 & female & Bachelor & 1 & mother \\
\hline Parent 5 & 38 & female & Bachelor & 2 (twins) & mother \\
\hline Parent 6 & 40 & female & Bachelor & 1 & mother \\
\hline Parent 7 & 43 & female & Bachelor & 1 & mother \\
\hline Parent 8 & 42 & female & Bachelor & 1 & mother \\
\hline Parent 9 & 44 & female & Master & 1 & Mother and father \\
\hline Parent 10 & 48 & female & Bachelor & 1 & father \\
\hline Parent 11 & 40 & female & Bachelor & 1 & father \\
\hline Parent 12 & 39 & female & Bachelor & 1 & father \\
\hline Parent 13 & 44 & male & Master & 1 & father \\
\hline Parent 14 & 45 & female & Bachelor & 1 & Student himself \\
\hline Parent 15 & 50 & male & Master & 1 & father \\
\hline
\end{tabular}

As for the interview results, $20 \%$ parents state they have no idea about students' English learning, and no parents confirm that they know students' English writing in details. However, $100 \%$ parents would love to be involved in students' English writing. 26.7\% parents declare that they've never tried any strategy to help their children. Therefore, $33.35 \%$ parents indicate that they never find out the barriers in helping children' English writing since they never involve in their children's English writing.

Mother takes the main responsibility in child's English learning in most of the participants' family, which accounts for $53.3 \%$ among the 15 parents. In China, mother takes responsibility of children's schooling in most family (Hu, 2002; Sun et al., 2017). However, none of them talked about the basic structure of English writing, such as title, organization, content, argumentation, and language use (Graham et al., 2016). None of them illustrate writing process (planning, drafting, evaluating, revising, and editing). With respect to writing strategy in parental involvement. $40 \%$ parents know a little to adopt their physical capital in students' English writing. However, parents do think that English writing is of great significance as in the research of Jiang's in 2003. Hence, $100 \%$ parents are eager to be involved in students' English writing with their full hearts. They express the great enthusiasm in the involvement, but they need the professional aids. Parents misunderstand parents' role in students' English writing. Parental involvement plays a supplement role in students' English writing, and it 
cannot replace teachers' role in English class (Wang, 2015).

There are 2 English teachers who are also head teachers in the classes taking part in the research (see Table 2). They are both young, energetic, and get their master's degree. The interview is a semi-structured interview to get how the teachers teach English writing in class and the attitudes to parental involvement (see Appendix B). The results of the interview for the teachers show that students have acquired English language use to write, including the grammar rules, the words. However, both teacherl and teacher 2 do not interpret writing process (Wang \& Han, 2017) and good writing structure in English writing (Graham et al., 2017).

Yet they all approve of the practice of parental involvement and believe parental involvement will be helpful in students' English writing. Clearly enough, for the practice of parental involvement, they hold less knowledge. They never show the capitals parents could use to help students in their English writing competence, which indicate the teachers never use parental involvement in supporting students' English learning.

Table 2. Background information of teachers

\begin{tabular}{lllll|}
\hline & Age & Gender & Academic Degree & Teaching years \\
\hline Teacher 1 & 30 & female & Master & 5 \\
Teacher 2 & 28 & male & Master & 5 \\
\hline
\end{tabular}

Parents could make use of parents' economical statues and parents' prior English writing experiences to help students' English writing. Current situation of students' English writing would cover current students' English writing both in class and at home. Therefore, the interview data for parents could determine how and what professional aids of parental involvement may get intervened. Notably, parents have to be aware of their helpful assets in parental involvement. All in all, physical capital provides some resources parents hold and adopt as well as facts parents must be alerted.

\section{Social Capital in the Model}

Social capital indicates social support, norms and obligations, in which mainly contains English writing norms, requirements and writing support in Second Language Acquisition parents have to know. Consequently, English Curriculum and Syllabus at Chinese Junior Middle School, Contrastive Analysis sand L1 usage in writing, cultivation of student's cultural awareness in writing would be incorporated in social capital of the model.

English curriculum standards for primary and secondary schools (2017 version) defines the curriculum objectives as the five main objectives and nine grading goals (MOE, 2017). The five main curriculum objectives contain Language Skills, Language Knowledge, attitudes to Learning, Learning Strategies and Cultural Awareness. Parents primarily focus on learning attitudes, learning strategy, and cultural awareness to develop students' English writing competence. These three skills could be acquired out of the English class with the help of parents' capital, since children spend much more time at home with parents compared to with English teachers.

Nine Grading Goals could be deemed to divide the main curriculum objectives into the detail. For the students at Junior Middle School, students are expected to meet Goal Grade Five in Grade nine (by junior middle school). In Goal Grade Five related to writing, students are supposed to collect and prepare for the writing resources based on writing requirements, to draft an essay or a letter independently, to use the frequent conjunctions to define the order and logic in the writing, to describe certain person or a type of event in simple English, and to write simple paragraph or instruction according to schema and table.

On the other hand, according the syllabus at Junior Middle School (2016 version), students are bound to write English in standard way, to dictate texts they have learned, to answer the text questions in written words, to have imitating writing, to write English letter, note, and notice based on the model writing, to paraphrase the reading and listening contents in written words, and lastly to express themselves in English written forms on the certain topic (English Syllabus at Junior Middle School, 2016).

Besides the curriculum and syllabus, parents need to comprehend how use native language (Chinese) to help students' English writing. Therefore, some concepts in SLA would be introduced roughly to parents. First, parents must know what makes a good language learner based on Rubin (1975). While others believe that one's language learning success is attributed to the strategies (Naiman et al., 1996). Therefore, English writing strategy need to be clarified. At the same time, parents could compare writing structure between Chinese and English, since parents hold better cognitive competence or physical capital compared to students. Furthermore, parents 
could use Chinese to discuss with students in constructing English writing before writing, such as guiding them to get writing idea and well-organized argumentation. However, parents must be aware of what make a good and well-organized English writing (Graham et al., 2016), and it concludes the Title, Organization, Content, Argumentation, and language use (Wang et al., 2017). Parents may utilize contrastive analysis based on their English learning experience to compare sentence structure, tense, writing logic between Chinese and English, leading students to build their own writing toolkit.

Cultural Awareness is beneficial for comprehending and using English correctly and properly. Chinese writing is typically circular, reflecting a culture that honors being polite and indirect to avoid offending anyone. While English writing is presented to be short, precise and direct statements that flow clearly and smoothly from one to the next. Understanding the culture would help parents and students more cautious in English writing. All in all, parents may get human capital after they hold physical capital and social capital.

\section{Human Capital in the Model}

Human capital refers to a package of parental involvement of instructional capability in helping students' English writing competence with the professional aids. Consequently, students' English writing strategy, E-tools usage in students' English writing, parenting styles, and home-based English writing activities would be included in developing students' English writing competence as human capital in the model.

Students' English writing strategy is to offer parents some English writing strategies in their parental involvement practice. Writing strategies are structured learning actions in the mental and physical way that students undertake to achieve writing goals. Therefore, writing strategies can be utilized to plan and set goals, draft, evaluate, revise and edit (Wang et al., 2017). Hence, parents would offer students help in selecting writing strategy, how to carry out each step of the strategy, and how to apply the strategy in writing (Graham et al., 2016). Simultaneously, parents would acknowledge the assessment to measure a good English writing so that they could help students' English writing with targeted purpose.

Some parental involvement writing strategy for students would be provided in the matter of before writing, when writing, and after writing based on the previous research on English writing strategy and students' writing practice. Before writing, parents could read with students together about the requirements of the writing task, clear writing purpose, write down the ideas coming to mind in Chinese (mind-mapping, brainstorming), write down the ideas coming to mind in English, write an outline (in Chinese, then in English), read more for argumentation. When writing, parents could find out some facts, data, research results in related reading materials (books, library, internet), use the dictionary to make sure the word spelling, reread the sentences to check the logic flow, reread the paragraphs to check the logic flow, clear ideas in the writing, and revise some parts together with students. Lastly, in the writing process after writing, parents can read the final draft thoroughly to check any errors along with students, check if effectively connected with the topic and its supporting ideas, push students to do spelling checking with the dictionary, verify proper usage of conjunctions in the writing, and inspect proper usage of grammar rules in the sentence writing with students.

However, there are still some traditional strategies which could be integrated in parental involvement. Parents can buy some model English writing books for students to read and write, and parents may sign up a training course of English writing online, including using APPs to practice English writing. furthermore, parents can guide students to learn the culture in English-speaking countries to fit in English writing, build English writing toolkit with students in word bank, English tense, and English conjunctions usage in writing based on students' learned English textbooks. Both parents and students would discuss and reflect every writing progress after each writing task, trying to avoid some downsides in the next writing. Students are getting accustomed to reading more English materials for the writing with the help of the parents. Both of them could choose and read something together.

However, many students enjoy its implementation in their English learning. Galy, Downey, and Johnson (2011) completed the surveys and showed that students enjoyed learning from online tutorials and E-tools, especially those that controlled audio and visual and shared good interaction. Warschauer (2002) found that students are often very aware of the necessity of technology for both effective language learning and developing information/communication literacies.

Parents might need help from E-tools usage in terms of checking students' writing. According to Eastwood and his colleagues (2012), the available tools might be helpful for students to achieve language writing goals and to become informed, critical technology consumers. Hence, an essential goal of E-tools in parental involvement is to help guide students and parents in the writing process with innovative way while increasing students' engagement and motivation in English writing. 
The E-tools can be utilized in outlining, brainstorming, and organization during the pre-writing stage, paraphrasing, summarizing, and organization during the writing stages. They can be used in feedback and peer review during the post-writing stages. Furthermore, the incorporation of web-based tools for students' writing has been studied by MacArthur (2009), who confirms the use of word processing, outlining, and concept mapping tools for struggling young writers. Consequently, many e-tools would be introduced to parents in different writing process.

Parenting style is another priority for parents to proceed as one human capital in the model of parental involvement. Students spend the majority of their time with parents, and families have an effect on students out of school time. In addition, families are among the most important determinants of students' learning attitudes, behavior, and overall wellbeing (Hoover-Dempsey \& Sandler, 1997; Epstein, 2001; Henderson \& Mapp, 2002; Jeroen, 2007). The degree of parental involvement is definitely influenced by many factors, such as family educational background, parental residence and parenting style which parents are adhered to one's cultural context (Bempechat, 1992; Dandapani, 2001; Sheila, 2005).

Research on relationship between parenting styles and children's learning achievements have been prominent for decades (Baumrind, 1971; Coleman, 1994; Darling \& Steinberg, 1993; Grusec \& Goodnow, 1994). Parenting style is most influenced by cultural value dimensions and socialization goals such as educational achievement in Asian families (Chao, 1994). Consequently, there is a firm need to discuss parenting style in students' English writing competence.

However, the culture plays a role in parenting style of the Asian family, and it must be understood to contextualize the family practices of parental involvement within Chinese culture. Chinese writing is different from English writing (Samantha, 2011), hence parenting style in students' English writing is worth demonstrating it in Chinese culture. According to Baumrind (1991), there are four types of parenting style, including the authoritarian, the authoritative, the permissive, and the neglectful parenting style. Two more parenting style would be added based on Chinese culture. Over-caring parenting style refers to parents are too protective for their children, while another one is Ignorant parenting style. Ignorant parenting style incorporates those parents who consider them as ill-literacy in English writing and weekend parents who do not take the responsibility for their child's English learning. They only meet their child on weekends.

Parents would reflect and check their own parenting style on account of the six parenting styles listed in the paper. In addition, parents may reconsider parenting style in the family, gaining more thoughts on it to promote parenting style in parental involvement of student' English writing competence.

The last one in human capital of parental involvement is home-based English writing activities. Rearing environment predicts children's academic performance and learning outcomes (Kiuru et al., 2012). Parental behaviors especially maternal involvement practice (responsibility, warmth, engagement) would be stable in affecting children's learning performance (Else-Quest et al., 2011) as in China. However, good parent-child interaction at home promotes home-based learning activity to increase children's learning performance (Rawashdeh et al., 2017). Home-based English writing activities would be conducted only if parents understand and use all the physical capital, social capital, and human capital in an appropriate way.

Parents should know the principle in constructing home-based writing activity. The principle contains the following:

* Parents' full dedication to students' English writing

\& Free negotiation with students on validity and utility of the activity

* Parent' available social capital and physical capital

\# Writing concepts and strategies from SLA

\& Planning and organizing

\$ Conducting and reflecting

\& Making some improvements for the next activity

As a result, validity and Utility would be the crucial aspect in building home-based learning activity (Eklund \& Brunt, 2017). However, Chinese family activity is restrained due to traditional monarch-subject relationship, in which the younger must obey and follow the old without conditions (Stevenson \& Lee, 1990). Therefore, some western family activities would be added so that parents could take example by them. Furthermore, home-based writing activity needs to be devised with discussing with students first, and it could be taken in any home-based activity (travelling, walking, visiting, a short excursion, hiking, shopping, and eating out). 


\section{The model in Parental Involvement}

Gonida \& Cortina (2014) confirmed that support of independent autonomy for junior middle school was the type of parental involvement to be more benefits for their English learning, while interference from parental involvement was the most harmful. To clarify the complex results concerning parental engagement on students' English writing competence, the model focuses on what particular elements of parental involvement in students' English writing can be the most effective ones for developing students' English writing competence and how.

All the parental involvement practices in the model are based on Brown's parental involvement formula (1998), in which parents' social capital and physical capital are the basis of parents' Human Capital. The underlying assumption of this model is that active involvement of parents at home ultimately results in better students' writing competence.

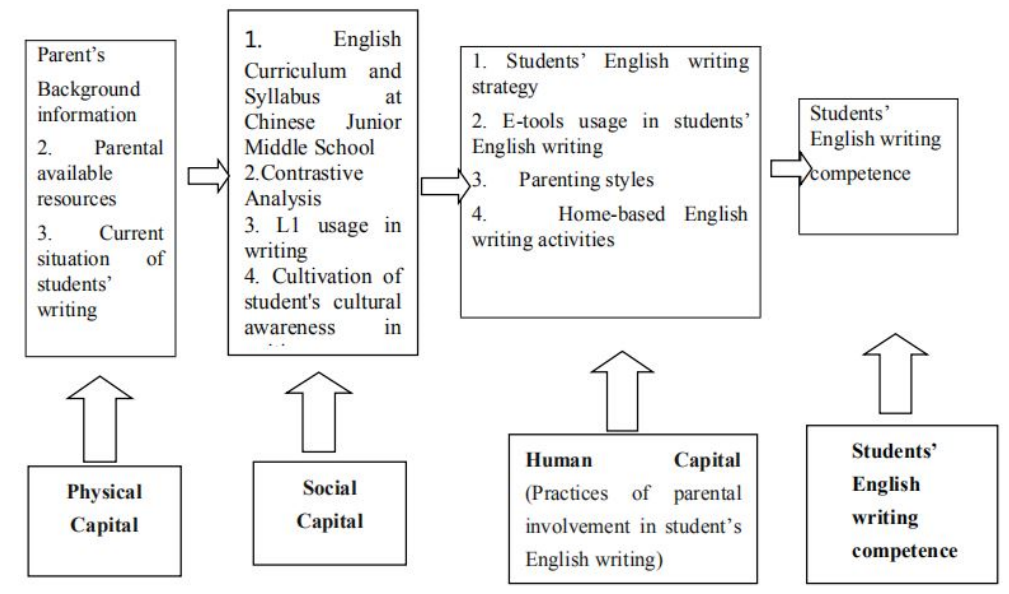

Figure 1. Model of Parental Involvement in students' English writing

\section{Conclusion}

This model is expected to offer parents some help on Chinese students' English writing, providing parents with some theoretical concepts and practical parental involvement practices at home. In the end, parents can devise their own home-based writing activities accordingly to fulfill the purposes of assistance in students' English writing competence. Parents are expected to take parental involvement as one of the obligations, then the efficiency of parental involvement may be desirable. It's well to be reminded that the role of parents in students' English writing is to help as a supplement role. Hence, students would take the responsibility to write. Most of the parental practice, both the parents and students must co-work to ensure the efficiency of parental involvement in students' English writing.

However, all the aspects of parental involvement in the model will be instructed and conducted in the workshop for parents. Seven workshops would be introduced to the parents based on the model, which contain Introductory, Contrastive Analysis and L1 usage, English learning strategy, cultivation of students' cultural awareness in writing, e-tools usage in students' English writing, parenting style, and home-based English learning activities. Therefore, analysis of the 7 workshops may be the further study on this topic.

\section{Acknowledgments}

The author would like to thank the participants of parents and teachers from No.1 Middle School of Chuxiong for their unselfish devotion of time and energy in the study, and CNU grants that have been supported this research.

\section{Conflict of interests}

The authors declare that there is no conflict of interests regarding the publication of this paper.

\section{References}

Baumrind, D. (1971). Current patterns of parental authority. Dev. Psychol. Monogr., 4(1), 1.

Baumrind, D. (1991). The influence of parenting style on adolescent competence and substance use. Journal of Early Adolescence, 11(1), 56-95. 
Bempechat, J. (1992). The role of parent involvement in children's academic achievement. Retrieved from http://files.eric.ed.gov/fulltext/ED322285 on June, 27/2017

Bourdieu, P. (1986). The forms of capital (R. Nice, Trans.). In J. C. Richardson (Ed.), Handbook of theory and research for the sociology of education (pp. 241-258). New York: Greenwood Press.

Bronfenbrenner, U. (1979). The ecology of human development: Experiments by nature and design. Cambridge, MA: Harvard University Press.

Brown, D. J. (1998). Schools with heart: Voluntarism and public education. Boulder, CO: Westview Press.

Chao, R. K. (1994). Beyond parental control and authoritarian parenting style: Understanding Chinese parenting through the cultural notion of training. Child Development, 65(4),1111-1119.

Chen, X., Bian, Y., Xin, T., Wang, L., \& Silbereisen, R. K. (2010). Perceived social change and childrearing attitudes in China. European Psychologist, 15(4), 260-270.

Cheung, C. S. S., \& Pomerantz, E. M. (2011). Parents' Involvement in Children's Learning in the United States and China: Implications for Children's Academic and Emotional Adjustment. Child Development, 82(3), 932-950.

Christian, K., Morrison, F. J., \& Bryant, F. B. (1998). Predicting kindergarten academic skills: Interactions among child care, maternal education, and family literacy environments. Early Childhood Research Quarterly, 13(3), 501-521.

Coleman, J. S. (1990). Foundations of social theory. Cambridge, MA: Harvard University Press.

Coleman, J. S. (1994). Family, school, and social capital. In T. Husen \& T. N. Postlethwaite (Eds.), International encyclopedia of education (2nd ed., pp. 2272-2274). Oxford: Pergamon Press.

Cortazzi, M., \& Jin, L. X. (1996). English teaching and learning in China. Language Teaching, 29(2),61-80.

Dandapani, S. (2001). A textbook of advanced educational psychology (2nd ed.). India: Delhi: Annmol publications Pvt. Ltd.

Darling, N., \& Steinberg, L. (1993). Parenting style as context: An interactive model. Psychological Bulletin, 113(5), 48-496.

Daubert, S. L., \& Epstein, J. L. (1993). Parents' attitudes and practices of involvement in inner-city elementary and middle schools. In N. F. Chavkin (Ed.), Families and schools in a pluralistic society (pp. 53- 71). State University of New York; Albany, NY.

Desforges, C., \& Abouchaar, A. (2003). The Impact of Parental Involvement, Parental Support and Family Education on Pupil Achievement and Adjustment: A Literature Review. Research Report No. 433, Department for Education and Skills, London. Retrieved from http://www.dfes.gov.uk/research/data/uploadfiles/RR433.pdf

Eastwood, K., Gallo, L., \& Piggot, J. (2012). Free, Effective eTools for Teaching Writing. In Serving for a Better World, Selected Proceedings of the 2012 Michigan Teachers of English to Speakers of Other Languages Conference (p. 65).

Eklund, M., \& Brunt, D. (2017). Measuring opportunities for engaging in meaningful home-based activities in housing services for people with psychiatric disabilities: Development of the perceived meaning of activity in housing (PMA-H). Eval Health Prof., 1-17.

Else-Quest, N. M., Clark, R., \& Owen, M. T. (2011). Stability in mother-child interactions from infancy through adolescence. Parenting, 11(4), 280-287.

English Syllabus at Junior Middle School. (2106). The Ministry of Education of the People's Republic of China.

Epstein, J. (2001). School, Family, and Community Partnerships. Boulder: Westview Press.

Galy, E., Downey, C., \& Johnson, J. (2011). The effects of using e-learning tools in online and campus-based classrooms on student performance. Journal of Information Technology Education, 10, 209-230.

Gao, X., (2006). Strategies Used by Chinese Parents to Support English Language Learning Voices of 'Elite' University Students. RELC Journal, 37(3), 285-298. Germany. Retrieved from IZA Paper Series (604).

Gonida, E. N., \& Cortina, K. S. (2014). Parental involvement in homework: Relations with parent and student achievement-related motivational beliefs and achievement. British Journal of Educational Psychology, (3), 376. 
Graham, S., Bruch, J., Fitzgerald, J., Friedrich, L. D., ..., \& Mathematica Policy Research, I. (2016). Teaching Secondary Students to Write Effectively. Educator's Practice Guide. What Works Clearinghouse. $\wedge^{\wedge} \mathrm{TM}^{\wedge}$ NCEE 2017-4002. What Works Clearinghouse. Retrieved from http://search.ebscohost.com/login. aspx?direct=true \&db=eric\&AN=ED569984\&site=eds-live\&authtype $=$ ip,uid

Grusec, J. E., \& Goodnow, J. J. (1994). Impact of parental discipline methods on the child's internalization of values: A reconceptualization of current points of view. Developmental Psychology, 30(1), 4-19.

Henderson, A. T., \& Mapp, K. L. (2002). A new wave of evidence: The impact of school, family, and community connections of student achievement. Austin, TX: National Center for Family \& Community Connections with Schools.

Hoover-Dempsey, K. V., \& Sandler, H. M. (1997). Why do parents become involved in their children's education? Review of Educational Research, 67(1), 3-42.

Hu, G. (2002). Recent important developments in secondary English-language teaching in the People's Republic of China. Language, Culture and Curriculum, 75(1), 30-49.

Jeroen, S. (2007). Family background and context effects on educational participation in five Arab countries. Retrieved from http://www.ru.nl/nice/workingpapers

Jeynes, W. (2003). A meta-analysis: The effects of parental involvement on minority children's academic achievement. Education \& Urban Society, 35(2), 202-218.

Jeynes, W. (2005). A meta-analysis of the relation of parental involvement to urban elementary school student academic achievement. Urban Education, 40(3), 237-269.

Jeynes, W. (2006). Standardized tests and the true meaning of kindergarten and preschool. Teachers' College Record, 108(10), 1,937-1,959.

Jeynes, W. (2007). The relationship between parental involvement and urban secondary school student academic achievement: A meta-analysis. Urban Education, 42(1), 82-110.

Jeynes, W. H. (1998). Examining the effects of divorce on the academic achievement of children: How should we control for SES? Journal of Divorce and Remarriage, 29(3/4),1-21.

Jiang, Y. (2003). English as a Chinese language. English Today, 19(2), 3-8.

Kashahu et al. (2014). The relationship between parental demographics, parenting styles and student academic achievement. European Scientific Journal, 10, 237-256.

Kiuru, N., Aunola, K., Torppa, M., Lerkkanen, M. K., ..., \& Nurmi, J. E. (2012). The role of parenting styles and teacher interactional styles in children's reading and spelling development. Journal of School Psychology, 50(6), 799-823.

MacArthur, C. A. (2009). Reflections on research on writing and technology for struggling writers. Learning Disabilities Research and Practice, 24(2), 93-103.

Mau, W. (1997). Parental influences on the high school students' academic achievement: A comparison of Asian immigrants, Asian Americans, and white Americans. Psychology in the Schools, 34(3), 267-277.

McBride, B. A., \& Lin, H. (1996). Parental involvement in pre-kindergarten at-risk programs: Multiple perspectives. Journal of Education for Students Placed at Risk, 1(4), 349-372.

MOE. (2017). English curriculum standards for primary and secondary schools. The Ministry of Education of the People's Republic of China.

Muller, C. (1998). Gender differences in parental involvement and adolescents' mathematics achievement. Sociology of Education, 71(4), 336-356.

Naiman, N., Frohlich, M., Stern, H., \& Todesco, A. (1996). The Good Language Learner. Clevedon: Multilingual Matters.

Peressini, D. D. (1998). The portrayal of parents in the school mathematics reform literature: Locating the context for parental involvement. Journal for Research in Mathematics Education, 29(5), 55-582. Perspective. Dordrecht: Kluwer Academic Publishers.

Rawashdeh, M., Al Zamil, M. G., Samarah, S., Hossain, M. S., \& Muhammad, G. (2017). A knowledge-driven approach for activity recognition in smart homes based on activity profiling. Future Generation Computer Systems. 
Rubin, J. (1975). What the 'Good Language Learner' can teach us. TESOL Quarterly, 41-51.

Samantha, S. (2011). How to overcome cultural differences in ESL writing. Retrieved from https://oupeltglobalblog.com/tag/samantha-stroh/

Shaver, A. V., \& Walls, R. T. (1998). Effect of Title I parent involvement on student reading and mathematics achievement. Journal of Research and Development in Education, 31, 90-97.

Sheila, K. (2005). The importance of the presence of the mother during the first three years. Retrieved from http://www.goodreads.com/author/show/893779

Singh, K., Bickley, P. G., Trivette, P., Keith, T. Z., Patricia, P. B., \& Anderson, E. (1995). The effects of four components of parental involvement on eighth-grade student achievement: Structural analysis of NELS-88 data. School Psychology Review, 24(2), 219-317.

Stevenson, H. W., \& Lee, S. Y. (1990). Contexts of achievement: A study of American, Chinese, and Japanese children. Monogr Soc Res Child Dev., 55(1-2), 1-123.

Sun, H. Q. (2010). Design of Cohesive Overall English Teaching Activities in Primary and Secondary School. Kunming: Yunnan University Press.

Sun, H. Q., Li, Y. W., \& Zhang, C. Y. (2017). Integrated and Coherent Teaching Capacity for English teachers in Elementary Education Stage. Changchun: Jilin University Press.

Wang, Y. Q. (2015). A trend study of the influences of parental expectation, parental involvement, and self-efficacy on the english academic achievement of chinese eighth graders (Vol. 44, pp. 45-68). York: Teachers College Press.

Wang, Z., \& Han, F. (2017). Metacognitive knowledge and metacognitive control of writing strategy between high- and low-performing Chinese EFL writers. Theory \& Practice in Language Studies, 7(7), 523.

Warschauer, M. (2002). A developmental perspective on technology in language education. TESOL Quarterly, $36(3), 453-475$.

Zdzinski, S. F. (1996). Parental involvement, selected student attributes, and learning outcomes in instrumental music. Journal of Research in Music Education, 44(1), 34-48.

\section{Appendix A Interview for parents}

Background information of parent:

Age:

Gender:

Academic Degree:

How many children do you have?

Who is mainly responsible for your child's English learning:

1. Do you know students' English learning at Junior Middle School?

2. What do you know about English writing at Junior Middle School?

3. Do you want to be involved in your child's English writing? What do you know about English writing strategy?

4. What strategies do you adopt in your parental involvement?

5. What types of barriers do you come across when you help your child's English writing? 


\section{Appendix B Interview for Teachers}

Background information of teacher:

Age:

Gender:

How many years have you been teaching?

1. What do you usually do in teaching writing?

2. What do you know about parental involvement?

3. Do you think it is a good idea to get parents involved in students' English writing?

4. What kinds of practice do you think that parents could be involved in students' English writing?

\section{Copyrights}

Copyright for this article is retained by the author(s), with first publication rights granted to the journal.

This is an open-access article distributed under the terms and conditions of the Creative Commons Attribution license (http://creativecommons.org/licenses/by/4.0/). 